\title{
牛の仕上げ体重が屠殺後の筋肉の $\mathrm{pH}$ 值，乳酸，グリコーゲン およびヌクレオチド関連物質の变化に及ぼす影響
}

\author{
小沢 忍**小石川常吉・千国幸一・吉武 充 \\ * 農水省中国農業試験場畜産部，大田市 694 \\ 農水省畜産試験場，茨城県筑波譨林研究団地 305
}

(1989. 9. 18 受付)

\begin{abstract}
要 約 平均仕上げ時体重 $675 \mathrm{~kg}$ (3頭) および $612 \mathrm{~kg}$ （3頭）の2 群のホルスタイン去勢牛の胸 最長筋を供試し，仕上げ時体重が屠殺後の筋肉の解糖系にかかわ物質の変化に及ぼす影響を調べた。 その結果，屠殺後における筋肉の $\mathrm{pH}$ 值の低下，グリコーゲンの隇少，ATP 等ヌクレオチドの変化か ら，高体重仕上げ区の方が低体重仕上げ区より解糖作用は速く進み，また最終 $\mathrm{pH}$ 值も低い傾向を示 した．解糖作用が完全に停止した時の筋肉中グリコーゲン濃度む，高体重仕上げ区が多かった．これら の測定値の差は，仕上げ時体重より，むしろ肥育度が反映したものと推察された。すおわち，脂肪蓄皘 が進んだ個体ほど死後の解糖作用が速く、グリコーゲン量も多いと考えられた，
\end{abstract}

日畜会報，61(5)：385-389，1990

生体では，筋肉のエネルギー源であるATP 濃度は 桓常的に保たれているのに対し，死後の筋肉でば，血液 からの酸素の供給が停止し, ATP の合成経路が絶たれ， ATP は漸次減少する。また，筋肉中に眝葴されている グリコーゲンの嫌気的解䅯が進み乳酸が生成，蓄積され る結果，筋肉の $\mathrm{pH}$ は一定の值（最終 $\mathrm{pH}$ 值）になる まで低下の一途をたどる．これらの死後における箭肉の 基本的な化学变化と死後硬直との関係は，BENDALL ら によって明らかにされている。最近，暗赤色牛肉 (Dark Cutting Beef) が問題になっており，暗赤色筋 肉の死後における解糖系を中心にした生化学的変化と， 生体条件との関連が次第に明らかにされつつある。すな わち，生体時における筋肉中のグリコーゲン量に影響を 及ばす品種, ストレス感受性の有無等の遺伝的要因 ${ }^{22}$, 輸送や絶食，屠殺時における苦䦕の程度等屠殺前の牛の 圾いに加加わるストレス等の環境要因 ${ }^{33}$ 上筋肉の死後変 化との関係加解明されている。しかし，牛の体重や肥㕕 度と牛肉品質に影響を及ぼすと考えられる筋肉の死後变 化との関係を究明した基礎的な研究はほとんどみられな い、そこで本報告では，仕上げ体重の異なる二つの牛群 を用い，屠殺後における筋肉の解糖系にかかわる物質の 量的变化を比較検討した。

日音会報，61（5）：385-389

\section{材料および方法}

供試牛はホルスタイン去勢牛 6 頭で，仕上げ時体重の 違いにより，低体重仕上げ区 (Low finishing body weight lot：L区）および高体重仕上げ区（High finishing body weight lot：H 区) の各々 3 頭ずつの 2 処理区を設けた（表 1)，表から明らかなように，仕上 げ体重の大きい $\mathrm{H}$ 区は，L 区に比べ肥育度の目安とな る肥育度指数，枝肉歩留りが高く，背脂肪む厚く，また 筋肉中水分含量屯低いこ之から，H 区の方か肥育度は 進んでいたものと考えられた。

屠殺解体後の枝肉加ら，胸最長筋を屠殺後 1 時間目， 以下 $3 ， 5 ， 8 ， 12 ， 24 ， 48 ， 72$ および 168 時間目の 9 回 採取し，試料は，第 6 胸椎部から第 13 胸椎部にかけて 順次採取し，分析に際しては空気に接している面は割除 した。なお，供試枝肉は $2^{\circ} \mathrm{C}$ に眝蔵した。

屠殺後 1 時間目上り枝肉の冷却曲線を観察するため, 両区における胸最長筋の腰部（第 2-3 腰椎部）の中心部 に温度センサーを挿入し，自記温度記録装置により温度 の変化を記録しだ.

分析は $\mathrm{pH}$ 值, グリコーゲン，乳酸および ATP， ADP, AMP, IMP にっいて行なった.

$\mathrm{pH}$ 值はニードル型複合電極を直接筋肉に挿入して測 
Table 1. Body weights, daily gain and carcase characteristics of experimental animals used in this study

\begin{tabular}{|c|c|c|}
\hline Item & $\mathrm{L} \operatorname{lot}^{11}$ & $H \operatorname{lot}^{21}$ \\
\hline No. of animals & 3 & 3 \\
\hline Initial weight of fattening & $300 \pm 75$ & $369 \pm 2$ \\
\hline Slaughter weight $(\mathrm{kg})$ & $612 \pm 25$ & $675 \pm 4$ \\
\hline Index of fattening degree ${ }^{3)}$ & $421 \pm 12$ & $481 \pm 19$ \\
\hline Fattening period (months) & $19.8 \pm 7.5$ & $11.9 \pm 1.0$ \\
\hline Daily gain (kg) & $0.53 \pm 0.01$ & $0.85 \pm 0.06$ \\
\hline Carcase weight $(\mathrm{kg})$ & $347 \pm 18$ & $398 \pm 5$ \\
\hline Dressing percentage ( 6$)$ & $59.2 \pm 1.7$ & $61.4 \pm 0.1$ \\
\hline $\begin{array}{l}\text { Back fat thidkness at } 13 \\
\text { rib }(\mathrm{mm})\end{array}$ & $6.0 \pm 3.7$ & $10.0 \pm 1.2$ \\
\hline $\begin{array}{l}\text { Moisture content of } \\
\text { M. longissimus }(\mathscr{6})\end{array}$ & $3.5 \pm 0.6$ & $9.8 \pm 7.5$ \\
\hline $\begin{array}{l}\text { Mean } \pm \text { standard deviation. } \\
\text { weight. 2) }: \text { High finishing } \\
\text { weight/withers height } \times 100\end{array}$ & - T & ng body \\
\hline
\end{tabular}

定した。

グリコーゲンの定量は $\mathrm{KOH}$ 抽出, Anthrone 発色 法による $\mathrm{VIES}^{4)}$ の方法に準拠して行なった。

ヌクレオチド関連物質は，見元および藤井の方法 より，高速液体クロマトグラフィー（島津：LC-3 A 型）を用いて分析した。 カラムは TSK gel DEAE-2 $\mathrm{SW}, 7.8 \mathrm{~mm} \mathrm{ID} \times 300 \mathrm{~mm}$ を用い，移動相は $0.1 \mathrm{~mol}$ リン䣨ナトリウム， $0.1 \mathrm{~mol} \mathrm{NaCl}(\mathrm{pH}: 6.8)$ で, 流速は $2.5 \mathrm{~m} l / \mathrm{min}$ であった，選定波長は $260 \mathrm{~nm}$ で, ATP， ADP， AMP，IMP の各標準物質の湘定から検 量線を作成しこれに基づき定量した。

乳酸の分析は，ヌクレオチド関連物質と同じ処理をし た上清を用いた．分析方法は，島津細管式等速電気泳動 分析計測定例に従った。すすなおち，上清液 $40 \mu \mathrm{l}$ を。 緗管式等速電気泳動分析装置（島津：IP-2 A 型）に注 入し，標準物質 L-乳酸（SIGMA）の検量線から定量 した.

\section{結果}

両区に抢ける屠殺後の枝肉の冷却曲線は図 1 に示すと おりである.

冷却直後の両区の枝肉温度差はほとんどみられなかっ たが，冷却開始後 5 6 時間目までは両区と屯急激に温 度は低下し，その程度は L 区で著しかった。その結果， 6 時間後では両区間の間に約 $5{ }^{\circ} \mathrm{C}$ の温度差が生じた。 そ の後 12 時間目まで曲線はなだらかになり，その時点の 温度は $\mathrm{L}$ 区で約 $4^{\circ} \mathrm{C}, \mathrm{H}$ 区で $8^{\circ} \mathrm{C}$ 之両区間の温度差は 保持された。 12 時間目以降, 両区の温度低下速度はさ

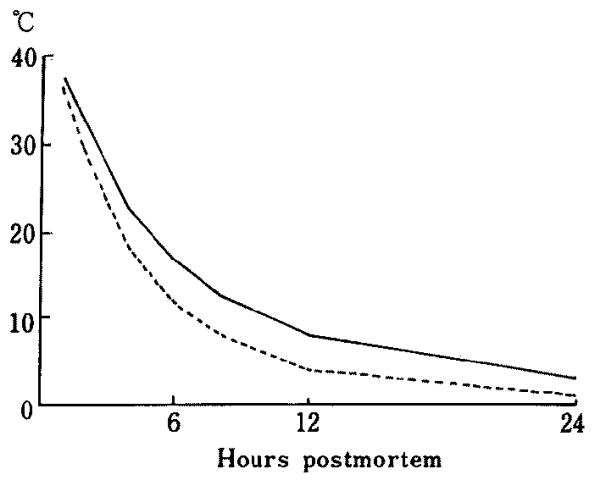

Fig. 1. Average chilling curves for M. longissimus (23 th lumbar vertebrae) in three carcases during 24 hours postmortem. - $:$ H lot, $\cdots \cdots . . .$. L lot
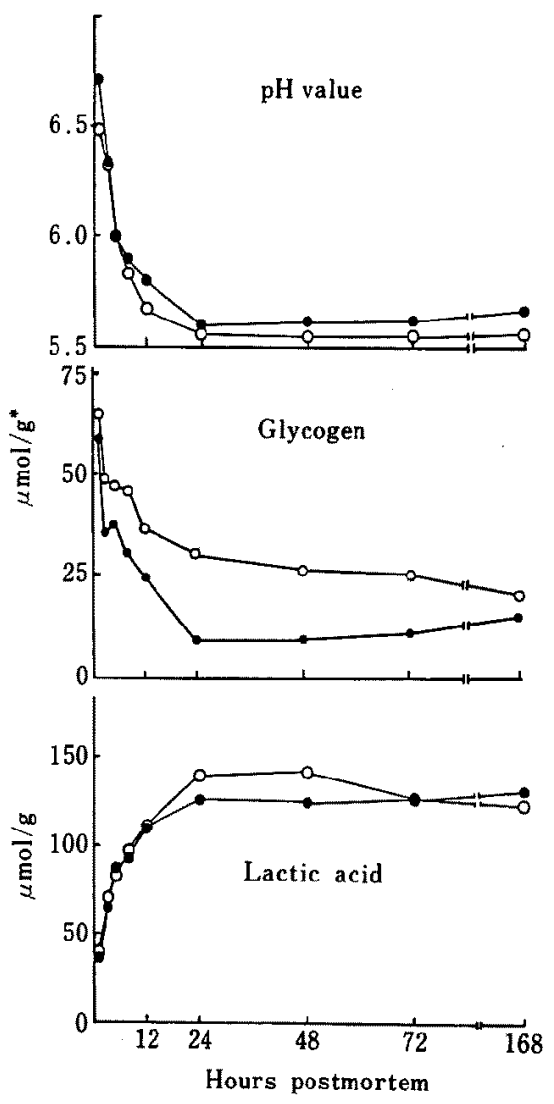

Fig. 2. Average changes in $\mathrm{pH}$ value, glycogen and lactic acid concentrations of $M$. longissimus during 7 days postmortem. $\mathrm{O}: \mathrm{H}$ lot, $\mathrm{O}: \mathrm{L}$ lot, *: Glucose equivalent 


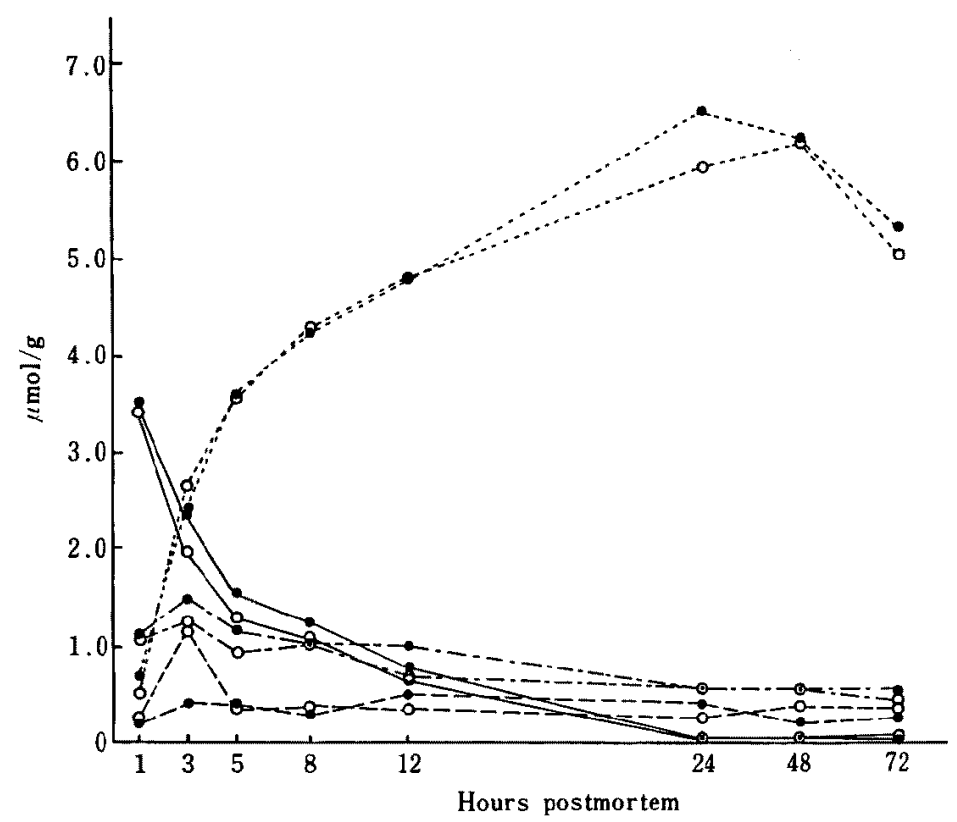

Fig. 3. Average changes in ATP and its breakdown products concentrations of M. longissimus during 3 days postmortem. $\bigcirc: \mathrm{H}$ lot, $\bigcirc: \mathrm{L}$ lot, — : ATP, , ... : ADP, ....: AMP, ....... : IMP

らにゆるやかになり，24時間目にかけて両区間の温度 差は接近しながら庫温に近づいた。

図 2 に屠殺後の $\mathrm{pH}$ 值, グリコーゲンおよび乳酸量 の変化を示した。

屠殺 1 時間後の $\mathrm{pH}$ 值は $\mathrm{H}$ 区で 6.5，L 区で6.7を 示し， $\mathrm{H}$ 区で速い低下を示した，最終 $\mathrm{pH}$ 値と推定さ れた屠殺後 24 時間目に扮ける值は，H区5.61，L区 で5.66, と接近したが，その後の眝蔵過程においてす H 区は低い值で推移した。

乳酸量の変化は両区とも屠殺後 24 時間目まで急速に 增加し, その後は $130 \mu \mathrm{mol} / \mathrm{g}$ 前後でプラトーの状態 で推移した。また，H区は L 区に比べ 48 時間目まで は高い值で推移した。

筋肉中グリコーゲンの量は，グルコース換算で居殺後 1 時間目で $\mathrm{H}$ 区は $66 \mu \mathrm{mol} / \mathrm{g}, \mathrm{L}$ 区で $59 \mu \mathrm{mol} / \mathrm{g}$ で $\mathrm{H}$ 区が多く，その後両区とも3 時間目までに激減し， さらに 24 時間目まで減少し続けた。 24 時間目では $\mathrm{H}$ 区で $30 \mu \mathrm{mol} / \mathrm{g}$, 一方 L 区で $10 \mu \mathrm{mol} / \mathrm{g}$ 程度で 7 日 までほぼ一定の值で推移した.

筋肉中の ATP, ADP, AMP および IMP 含量の変 化は図 3 に示すとおりである.

ATP量は, 屠殺後 1 時間目では両区とむ 3.5 $\mu \mathrm{mol} / \mathrm{g}$ 程度存在したが, 眝蔵時間之ともに急激に減 少し， 8 時間目では当初の約 $1 / 3$ 程度になった。 その後 24 時間目までは濑次減少し続け，ほとんど消失した。 その間の隇少速度は H 区がやや速い傾向を示した。 $\mathrm{ADP}$ 量は屠殺後 1 時間から 8 時間目まで $1 \mu \mathrm{mol} / \mathrm{g}$ 程度の值を示し, ATP と同様 H区でやや低い值であ った．その後は $0.5 \mu \mathrm{mol} / \mathrm{g}$ 程度でほぼ一定の值で推 移した. AMP 量は両区とも，屠殺直後 $0.2 \sim 0.3 \mu \mathrm{mol} /$ $\mathrm{g}$ で低いレベルであったが，3時間目以降やや上昇傾向 を示した後，再び減少する傾向を示した，一方，IMP 量は廜殺後 24 時間目までは急增したが，その後次第に 低下する㑯向がみられた。

\section{考察}

屠殺後の $\mathrm{pH}$ 值の低下速度は, 解糖作用の速さを反 映する信頼できる指標とされており，またこの解䌅作用 は，筇肉の温度に強く影響されることが知られてい

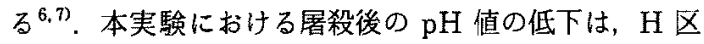
が L 区より速く，最終 $\mathrm{pH}$ 值と考えられた 24 時間目 $の \mathrm{pH}$ 值も $\mathrm{H}$ 区が低い值を示した。しかし，両区間に は統計的に有意な差はみられなかった，両区を込みにし た場合の屠殺後 6 時間目の枝肉温度と最終 $\mathrm{pH}$ 值との 
小沢 - 小石川・ 千国・吉武

関係をみると， $\mathrm{r}=0.94 （ \mathrm{p}<0.01 ）$ の相関がみられた。 このことから，pH 值に及ぼす要因の一つとして，仕上 げ休重よりむしろ断熱材としての蓄積脂肪の多少が反映 されたものと推定された。

死後の筋肉中のグリコーゲンは，解糖作用の進展にと あない急速に減少する. BODWELL ら ${ }^{8)}$ は約 $386 \mathrm{~kg} の$ ヘレフォード雌牛における胸最長筋のグリコーゲンの変 化を調べている．本実験におけるL区拈りグリコーゲン 量の变化は，ほぼ彼らの钼祭結果上一致した。一方，H 区では，L区上り高い水準で推移し，解糖作用が停止 した時点のグリコーゲン量も多い傾向を示した，しかし， 両区の問には統計的な有意差は認められなかった。

解精作用が停止した時の筋肉中に残存するグリコーゲ ン量は，生体で運動を負荷しない時の，いわ吼休息筋 の值の 2 30\% と大きな幅が報告されている ${ }^{9}$. これら の值は, 品種, 初期のグリコーゲン量, 屠殺前のストレ ス, 解糖作用の速さ等様々な要因加関与している ${ }^{10)}$. 本 実験では，画区を込みにした場合，体重，肥育度指数わ よび皮下脂肪之屠殺後 24 時間目に怙けるグリコーゲン 量之の間には，それぞれ $\mathrm{r}=0.81(\mathrm{NS}), 0.90(\mathrm{p}<$ $0.05)$ および $0.83(\mathrm{p}<0.05)$ という相関があり，とく に肥育度に関する形質との相関が高かった．このことか ら，肥育度の進んでいる個体はど，生体時における筋肉 中のグリコーゲン量が多く、また解糖作用が停止した時 点のグリコーゲン量も多いあのと考えられた．しかし， 筋肉グリコーゲンと筋肉中の水分含量之の間には, 死後 1 時間目では $\mathrm{r}=0.07$, および同じく 24 時間目では $\mathrm{r}$ $=-0.16$ と両者の間には有意な相関関係は認められな かった，筋肉中の水分含量は脂肪含量之負の相関が高い ことが認められており ${ }^{111}$, 従って筋肉中のグリコーゲン 量は筋肉中の脂肪含量とは直接的な関係はみられないす のと考えられた。

筋肉中のグリコーゲンは骕気的解糖経路で乳酸を生成 する過程で ATP を生じ，また高エネルギー燐酸を含 をクレアチン燐酸（CrP）は次の反応により ATPを 産生する。

$$
\mathrm{CrP}+\mathrm{MgADP} \frac{\text { creatine kinase }}{\mathrm{MgATP}}+\mathrm{Cr}
$$

従って，屠殺後グリコーゲン量とクレアチン橉酸濃度は 隇少の一途をたどるあのの，これらがある一定濃度以下 になるまでは，ATP は再合成されるため，ATP 量の 減少は幾分途れて始まるとされている9。休息筋におけ る牛胸最長筋の ATP 量は $6 \mu \mathrm{mol} / \mathrm{g}$ 程度であり ${ }^{1)}$, 本実験に极ける屠殺後 1 時間目の ATP 濃度は, 両区 ともすでに $3.5 \mu \mathrm{mol} / \mathrm{g}$ 程度に低下していた，従って，
この時までにグリコーゲンおよびクレアチン䗲酸の分解 はかなり進んでいたものと考えられた，ATP の減少速 度は，䈘肉の温度により大きく影響される ${ }^{22}$.しかし， 本実験では冷却が遅れた H区の ATP 分解速度は L 区に比べ幾分速い傾向がみられたが，統計的には有意差 は認められなかった。

$\mathrm{ADP}$ 濃度は，休息筋では約 $1.0 \mu \mathrm{mol} / \mathrm{g}$ 程度存在 する ${ }^{1)}$. NEWBALD and SCOPES ${ }^{12)}$ の牛胸骨下頑筋を用 いだ試験によれば，ADP 濃度は屠殺後 5〜6時間まで は低下しない，本実験においても，ADP レベルは，屠 殺後 8 時間目までは約 $1.0 \mu \mathrm{mol} / \mathrm{g}$ の值を保ち, 彼ら の結果とほぼ一致した。このことは，ADP 量はATP がある程度消費された時点，すなわち ATP が $1: 0$ $\mu \mathrm{mol} / \mathrm{g}$ 以下に減少した頃から低下し始めるすのと考 えられた， $\mathrm{ADP}$ 量の変化は $\mathrm{H}$ 区でやや低い傾向を示 したが，その差は明瞭ではなかった。

休息筋の AMP 濃度は 0.2 0.3 $2 \mu \mathrm{mol} / \mathrm{g}$ と非常に 低い" ${ }^{1)}$. NEWBALD and SCOPES ${ }^{12)}$ の胸骨下顎筇を用い た研究によれば，AMPレベルは，屠殺 10 時間の間に 2 〜3 倍に増加した後, 24 時間目までにまたもとのレベル に戻ることが認められている、本実験でも屠殺 1 時間目 で $0.2 \sim 0.3 \mu \mathrm{mol} / \mathrm{g}$ と低い值を示し，その後やや上昇 する傾向がみられ，彼らの結果と同様な傾向であった。 また，AMP 量の変化には両区間に差が認められなかっ た.

IMP の休息筋における濃度は $0.5 \mu \mathrm{mol} / \mathrm{g}$ 程度 ${ }^{1)}$ と 少ない，屠殺後に打けるIMP 量は，ATP の消失とと 6に急上昇した。 また，24時間目以降次第に減少傾向 を示したのは，さらにイノシシやヒポキサンチンにまで 分解が進んだためであろう。

以上の結果, 死後における筇肉の解糖作用の速さ, 最 終 $\mathrm{pH}$ 值㧍よび残存グリコーゲン量に対しては仕上げ 時体重より，肥育度すなわち体脂肪の蓄穂程度が強い影 響を及ばす毛のと考えられた。

\section{文献}

1) Bendall, J.R., in The Structure and Function of Muscle. vol 2. 2nd ed. (Bourne, G.E, ed.) 37-59. Academic Press. London. 1973.

2) Holmes, J.H.G., C.R. AshmoRe and D.W. Robinson, J. Anim. Sci., 36 : 686-694. 1973.

3) Chrystall, B.B., C.E. Devine, C.L. Davey and A.H. KIRTon, in The Problen of Dark-Cutting Beef. (HOOD, D.E. and P.V. TARRENT, ed.) 269-282. Martinus Nijhoff Publishers. Hague. 1980.

4) VIES, J.V., Biochem. J., $57: 410-416.1954$.

5）見元萃一・藤井 䁷, 東海水研報，46：69-78。 1966 . 
6) Bata-Smith, E.C. and J.R. Bendall, J. Physiol., $110: 47-65.1949$.

7) Cassens, R.G. and P.P. Newbald, J. Food Sci, 32 : 13-14. 1967.

8) Bodwell, C.E., A.M. Pearson and M.E. Spooner, J. Food Sci., 30 : 766-772. 1965.

9) Greaser, M.L. in Muscle as Food. (Bechtel, P.J. ed.) 39-52. Academic Press. London. 1986.

10) Pearson, A.M. and R.B. Young, in Muscle and Meat Biochemistry. 396-399. Academic Press. London. 1989.

11）田叶彰治，酪宸科学の研究，34:27-35. 1985.

12) Newrald, R.P. and P.K. Scopes, Biochem. J., 105 : 127-136. 1967.

\title{
Effect of Slaughter Body Weight on Postmortem Changes in $\mathrm{pH}$ Value, Glycogen, Lactic Acid and Nucleotides of Longissimus Muscle in Holstein Steers
}

\author{
Shinobu Ozawa*, Tsunekichi KoIshirawa, \\ Koichi Chikuni and Mitsuru Yoshitake \\ * Chugoku National Agricultural Experiment Station, Oda-shi 694 \\ National Institute of Animal Industry, Tsukuba Norin Kenkyu \\ Danchi, Ibaraki-ken 305
}

Th experiment was conducted to examine the effect of finishing body weight on the changes in some substances relating with postmortem glycolysis of longissimus muscle taken from high finishing body weight lot ( $\mathrm{H}$ lot : $675 \mathrm{~kg}$ in average for three animals) and low finishing body weight lot ( $\mathrm{L}$ lot: $612 \mathrm{~kg}$ in avarage for three animals) in Holstein steers. During earlier stage of postmortem, relative glycolitic rate assumed by change of $\mathrm{pH}$ fall, rate of depletion in glycogen and ATP breakdown developed faster in $\mathrm{H}$ lot than $\mathrm{L}$ lot. $\mathrm{H}$ lot had a tendency to lower ultimate $\mathrm{pH}$ value, with higher level of residual glycogen concentration than those of $L$ lot. The results suggested that rate of glycolysis, ultimate $\mathrm{pH}$ value and glycogen concentation were influenced by rather degree of fat accumulation in carcase than body weight.

Jpn. J. Zootech. Sci., 61 (5) : 385-389, 1990

Key words: Postmortem glycolysis, Muscle nucleotides, Muscle pH, Mucle glycogen, Muscle lactic acid 